\title{
Temperature-Induced Moisture Migration in Reduced-Fat Cheddar Cheese ${ }^{1}$
}

\author{
A. Olabi and D. M. Barbano \\ Northeast Dairy Foods Research Center \\ Department of Food Science, \\ Cornell University, Ithaca, NY 14853
}

\begin{abstract}
Moisture migration during cooling of 290-kg Cheddar cheese blocks is a problem. The problem is of greater magnitude in reduced and low fat varieties. The objective of this study was to design and evaluate the performance of a laboratory-scale apparatus for simulation of temperature induced moisture migration in $290-\mathrm{kg}$ blocks of Cheddar cheese. Two apparati were designed to produce a systematic temperature gradient in small cheese slabs over a 36 - $\mathrm{h}$ period to simulate the temperature gradient that develops during cooling of a $290-\mathrm{kg}$ block. One of the apparati was designed to induce a moisture migration downwards with gravity and the other against gravity. The apparati produced moisture migration ranges of 9.7 and $6.4 \%$, for the apparatus to induce moisture migration downwards and upwards, respectively. The moisture moved from areas of warm cheese to areas of cold cheese during cooling, as occurs in 290-kg blocks. These ranges were comparable to those obtained with 290-kg reduced-fat Cheddar blocks. In addition, small but significant differences in $\mathrm{pH}$ were created within slabs. The direct effect of the temperature gradient on moisture migration within cheese slabs appeared to be more important than the possible impact of the small $\mathrm{pH}$ gradient produced within the cheese by the temperature gradient.
\end{abstract}

(Key words: reduced-fat Cheddar, moisture migration, 290-kg blocks)

\section{INTRODUCTION}

In the United States, Cheddar cheese was traditionally produced in 18-kg blocks. A large proportion of Cheddar cheese manufacturing shifted to 290-kg

\footnotetext{
Received February 23, 2002.

Accepted March 25, 2002.

Corresponding author: David M. Barbano; e-mail: dmb37@ cornell.edu.

${ }^{1}$ Use of names, names of ingredients, and identification of specific models of equipment is for scientific clarity and does not constitute any endorsement of product by authors, Cornell University, or the Northeast Dairy Foods Research Center.
}

blocks in the late 1970's and early 1980's to reduce costs and improve efficiency. The approximate dimensions of a $290-\mathrm{kg}$ block are $71 \mathrm{~cm}$ high $\times 56 \mathrm{~cm}$ wide $\times 71 \mathrm{~cm}$ long. The 290-kg blocks reduced labor and handling costs, on the job lifting injuries, intermediate packaging costs (Mesa-Dishington et al., 1987), and trim loss when these blocks were used to produce exact weight pieces for the retail market. Even though the handling of the 290-kg blocks with forklifts proved to be practical and efficient, the cooling of the cheese emerged as a major challenge to product quality. There was a systematic variation in the composition of the cheese, especially moisture, in different locations of the block leading to variations in cheese flavor and texture.

Reinbold et al. (1988) reported a 5.73\% moisture range between the center and sides of $290-\mathrm{kg}$ blocks of stirred-curd Cheddar cheese after being held at $6^{\circ} \mathrm{C}$ for $7 \mathrm{~d}$. The moisture migration occurred from areas of high to low temperature and resulted in a porous cheese structure because the curd granules did not fuse completely. The moisture migration was minimal $(0.96 \%)$ when the cheese blocks were held at $22^{\circ} \mathrm{C}$ for $7 \mathrm{~d}$ before initiation of cooling, but this storage temperature before cooling produces other undesirable microbiological problems. However, because this treatment did achieve a large reduction in moisture migration during cooling, it appears that other physical or chemical changes in the cheese that occur during the $7 \mathrm{~d}$ at $22^{\circ} \mathrm{C}$ produced conditions that prevented the temperature-driven moisture migration.

Reinbold et al. (1992a) conducted another study in which the temperature, $\mathrm{pH}$, and moisture at different locations within $290-\mathrm{kg}$ blocks were monitored during $12 \mathrm{~d}$ of cooling at $2.2^{\circ} \mathrm{C}$. Within $24 \mathrm{~h}$, a temperature gradient from the interior $\left(35^{\circ} \mathrm{C}\right)$ to the exterior $\left(15^{\circ} \mathrm{C}\right)$ was developed. The moisture percentages at the beginning of cooling were about 41.8 and $37.5 \%$ at the center and side of the block, respectively, but were changed to 34.5 at the center and $39.9 \%$ at the side after $24 \mathrm{~h}$ of cooling. The $\mathrm{pH}$ in the center of the blocks decreased while $\mathrm{pH}$ near surface remained the same. The authors indicated that further work is needed to deter- 
mine whether moisture transfers in response to a $\mathrm{pH}$ gradient that is in turn created by the temperature gradient or whether moisture transfers in response to temperature-related physical phenomena.

Reinbold et al. (1992b) also examined the effect of container material on moisture migration in $290-\mathrm{kg}$ Cheddar blocks. Twelve days were needed for the center of the block to cool to $2.2^{\circ} \mathrm{C}$ in stainless steel, whereas in plywood $14.75 \mathrm{~d}$ were needed. The authors found that materials and conditions that produced more rapid cooling and larger temperature gradients from the surface of the 290-kg block to the center produced the largest moisture gradients within the block.

Barbano (2001) conducted a study to characterize the impact of nonuniform moisture distribution in 290-kg Cheddar blocks on the accuracy of sampling the cheese for moisture determination. Moisture was lowest in the center of the block and higher at all outside surfaces. The moisture difference between the center and the outside surfaces of the blocks was about $5 \%$. The moisture migrated from the center of the blocks toward all outside surfaces. Thus moisture moved up, down, and laterally within a block. The problem of moisture nonuniformity gets worse as the fat content of the cheese is reduced and the moisture content is increased, reaching 6 and 7 to $9 \%$ in reduced-fat and fat-free Cheddar varieties, respectively.

The physical size of $290-\mathrm{kg}$ blocks of cheese and the quantity of cheese in a $290-\mathrm{kg}$ block make it difficult to carry out controlled studies of temperature-induced moisture migration, particularly at a university or research center. Therefore, our objective was to design and evaluate the performance of a laboratory-scale apparatus for simulation of temperature-induced moisture migration in $290-\mathrm{kg}$ blocks of Cheddar cheese.

\section{MATERIALS AND METHODS}

\section{Equipment Design and Operation}

An apparatus was designed to produce a systematic temperature gradient in small cheese slabs over a 36$\mathrm{h}$ period to simulate the temperature gradient that develops during cooling of a $290-\mathrm{kg}$ block. The apparatus consisted of a water bath (Figure 1a) and a device designed to gradually raise or lower vacuum packaged slabs of cheese (Figure 1c) in or out of a water bath. The device for raising or lowering the cheese slabs consisted of a rotating cylinder (Figure 1c), mounted on a shaft, which was driven by two gear motors (Dayton 2L001A, Dayton Electric Mfg. Co., Niles, IL) in a series (Figure 1d) so that the rotation speed of the cylinder was one revolution per $36 \mathrm{~h}$. The diameter of the cylinder was selected so that the cheese slabs were raised or lowered at a speed of $0.4233 \mathrm{~cm} / \mathrm{h}$. Seven metal screws were attached to the rotating cylinder and a plastic coated wire was attached to each screw. Six cheese slabs (Figure 1b) and one counter weight (Figure 1e) were suspended from these wires. The counter weight weighed $3 \mathrm{~kg}$ (equivalent to the total weight of the six cheese slabs). If fewer slabs were used, then a lighter counter weight was used. As the cylinder rotated and the cheese slabs were raised or lowered, the counter weight moved in the opposite direction. The weight was used to counteract the weight of the cheese slabs and to prevent excessive pressure on the rotating cylinder thus allowing it to rotate smoothly at the required rate. In addition, a submersible pump (Little Giant, NK-1 Series, Oklahoma City, OK) was set inside the water bath to circulate the water and help maintain temperature uniformity in the bath.

Two of these temperature-gradient apparati were built, one designed to produce a temperature driven gradient in moisture with the moisture moving with gravity (i.e., toward the bottom of the cheese slab) and the other was designed to make the water move against gravity (i.e., toward the top of the cheese slab). The inside dimensions of the first water bath (Magni Whirl, Blue M Electric Company, Blue Island, IL) were: $45.5,30.5$, and $23.9 \mathrm{~cm}$ for length, width, and depth, respectively, and it was set at a temperature of $27 \pm 0.5^{\circ} \mathrm{C}$. The second water bath was an insulated tank with copper cooling coils immersed in the tank. Propylene glycol at $1.7^{\circ} \mathrm{C}$ was circulated through these coils to maintain the second water bath at $3 \pm 0.5^{\circ} \mathrm{C}$. The apparatus with the $27^{\circ} \mathrm{C}$ water bath was held in a $3 \pm 0.5^{\circ} \mathrm{C}$ walk-in cooler and the apparatus with the $3^{\circ} \mathrm{C}$ water bath was held in a $27 \pm 0.5^{\circ} \mathrm{C}$ walk-in cooler.

In an experiment, vacuum-packed slabs of cheese that were placed in the $27^{\circ} \mathrm{C}$ water bath were gradually raised out of the water bath into the $3^{\circ} \mathrm{C}$ air in the room over a 36 -h period. At the same time, other slabs of cheese from the same block were suspended from the rotating cylinder in $27^{\circ} \mathrm{C}$ air and gradually lowered into the $3^{\circ} \mathrm{C}$ water bath over a 36 -h period. Therefore, in one case the cold front advanced from the bottom to the top of the slab and in the other the cold front advanced from the top of the slab to the bottom.

\section{Cheese-Making Procedure}

Reduced-fat Cheddar cheese was made by transferring $215 \mathrm{~kg}$ of $4^{\circ} \mathrm{C}$ pasteurized skim milk to a cheese vat (model 4MX; Kusel Equipment Co., Watertown, WI). The fat content of the skim milk was adjusted 


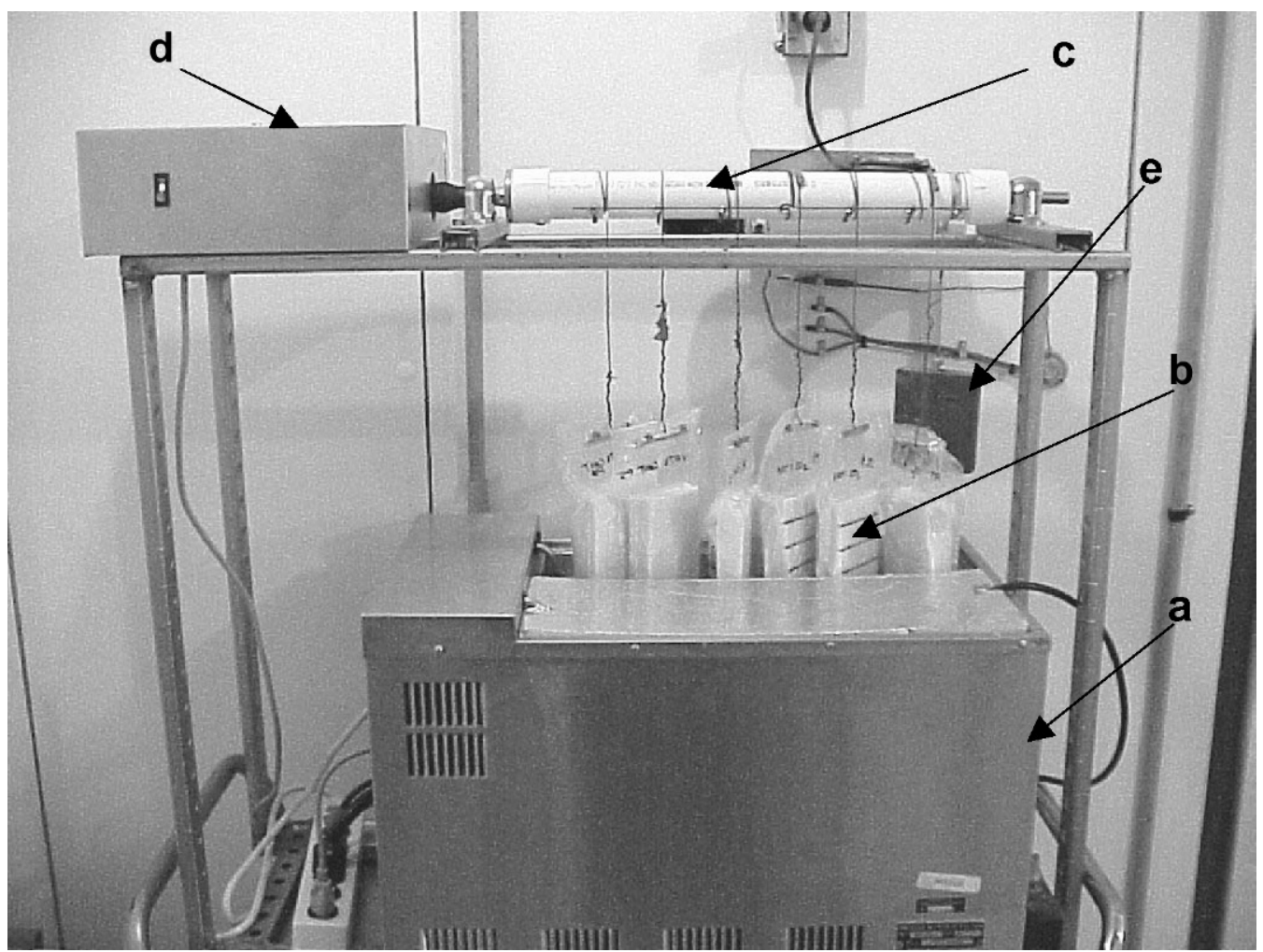

Figure 1. Apparatus to produce a temperature gradient with cheese slabs over a 36 h period: (a) water bath; (b) cheese slab; (c) rotating cylinder; (d) gear box; and (e) weight.

by adding pasteurized heavy cream (approximately $40 \%$ fat) to achieve a $50 \%$ fat reduction (compared to full-fat Cheddar cheese) in the final cheese. Fat content of cream was determined using the Babcock method [(Association of Official Analytical Chemists, 2000); method number 33.2.27, 989.04]. The milk was heated to $31^{\circ} \mathrm{C}$ over a period of 25 min while the culture (Culture 911, DVS, Chr. Hansen Inc., Milwaukee, WI) was thawed for $25 \mathrm{~min}$ in a water bath at $37^{\circ} \mathrm{C}$. At the end of $25 \mathrm{~min}$, the culture was added at a rate of $0.24 \mathrm{ml} / \mathrm{kg}$ of milk and the mixture was ripened for 50 min. After 45 min of ripening, Annatto color (AFC WOS 550; Rhodia Inc., Madison, WI) was added at a rate of $0.0033 \mathrm{ml} / \mathrm{kg}$ of milk. Following $50 \mathrm{~min}$ of ripening, double strength chymosin derived by fermentation (Chymax Extra, Chr. Hansen Inc., Milwaukee, WI) was added at a rate of $0.1 \mathrm{mg} / \mathrm{kg}$ of milk. Before the addition, the chymosin was diluted in 200 $\mathrm{ml}$ of water reduced in hardness by reverse osmosis. A 30-min period from chymosin addition to cutting was used. The coagulum was cut with $1.2-\mathrm{cm}$ wire cheese knives and then allowed to heal for $5 \mathrm{~min}$. Healing was followed by slow agitation for $10 \mathrm{~min}$ at $31^{\circ} \mathrm{C}$. The temperature was increased from 31 to $33^{\circ} \mathrm{C}$ and from 33 to $37^{\circ} \mathrm{C}$ in two 15 -min intervals. The curd plus whey was stirred at $37^{\circ} \mathrm{C}$ until a whey $\mathrm{pH}$ of 6.2 was achieved. At this point, most of the whey was drained and the curd-whey mixture was stirred at $37^{\circ} \mathrm{C}$ until a curd $\mathrm{pH}$ of 5.8 was attained (this took around 40 to $45 \mathrm{~min}$ ). Next, additional whey was removed and cold water (approx. $5^{\circ} \mathrm{C}$ ) was added until a curd temperature of $28^{\circ} \mathrm{C}$ was achieved. Stirring was continued until a curd $\mathrm{pH}$ of 5.6 was achieved. At $\mathrm{pH} 5.6$ the mixture of whey plus water was drained from the curd, the curd was weighed, and salt was added in three equal portions (total of $2.7 \% \mathrm{wt} / \mathrm{wt}$ ) with a 5 -min interval between applications. The curd plus salt was mixed for about 1 min after each salt addition. The salted curd was put into an $18-\mathrm{kg}$ stainless steel Wilson hoop and pressed, using a hydraulic A-Frame press (Model AFVS, Kusel Equipment Co., Watertown, WI), at $10 \mathrm{psi}(70 \mathrm{kPa})$ for $30 \mathrm{~min}$ followed by $60 \mathrm{psi}(420 \mathrm{kPa})$ for $4.5 \mathrm{~h}$ at room temperature. Immediately after pressing, the block of cheese was cut into slabs that were vacuum packaged and placed into the temperature gradient apparatus.

Titratable acidity [(Marshall, 1992); method number $15.3 \mathrm{~A}$ ] of the milk and whey, and $\mathrm{pH}$ (model HA405, Mettler Toledo electrode, Columbus, $\mathrm{OH}$ and Accumet pH meter, model 915; Fisher Scientific, Fair 
Lawn, NJ) of the milk, whey and cheese were determined during cheese manufacturing. The electrode was immersed in $3 \mathrm{M} \mathrm{KCl}$ storage solution at $38^{\circ} \mathrm{C}$ between $\mathrm{pH}$ measurements to improve response speed and stability and to control calibration. Reference solutions (Fisher Scientific, Fair Lawn, NJ) for $\mathrm{pH} 4$ (SB 101-500) and $\mathrm{pH} 7$ (SB 107-500) were used at $38^{\circ} \mathrm{C}$ for calibration of the $\mathrm{pH}$ meter. The actual $\mathrm{pH}$ of the reference buffers was calculated for $38^{\circ} \mathrm{C}$ based on the temperature coefficients recommended by the buffer manufacturer.

\section{Sampling}

Immediately after the 18-kg block of cheese was removed from the press it was cut and sampled in a walk-in climate control room at $27 \pm 0.5^{\circ} \mathrm{C}$. The internal temperature of the blocks of cheese was approximately $25^{\circ} \mathrm{C}$. The $18 \mathrm{~kg}$ pressed block was cut in half at the middle and then six $17.78 \times 7.62 \times 2.54 \mathrm{~cm}$ (length, width, thickness) slabs of cheese were obtained from the center of each block. These slabs were immediately vacuum packaged (Multi Vac model 160; Kock, Kansas City, MO) in a 3 mil polyethylene bag $(25.4 \times 45.7 \mathrm{~cm}$, standard barrier; Koch, Kansas City, MO). In addition, a slab of $28.6 \times 14.0 \times 2.54 \mathrm{~cm}$ (length, width, thickness) was cut from the 18-kg cheese block and vacuum packaged (Multi Vac model 160; Kock, Kansas City, MO) in a 3-mil polyethylene bag (Nelson-Jameson, Marshfield, WI). This slab was cooled immediately and stored at $4^{\circ} \mathrm{C}$ for the cheese composition analysis.

After the six $17.78 \times 7.62 \times 2.54 \mathrm{~cm}$ cheese slabs were vacuum packaged, each bag was marked with horizontal lines so that each $2.54-\mathrm{cm}$ position was identified (Figure 2). The different positions were numbered from the bottom to the top, 1 for the bottom and 7 for the top (Figure 2). The slabs were attached to the suspension wires (Figure 1c) on each apparatus. For the apparatus designed to cause moisture to migrate to the bottom of the cheese slab, the position 1 of the slabs was immersed in the $3^{\circ} \mathrm{C}$ water bath while positions 2 through 7 were exposed to the $27^{\circ} \mathrm{C}$ air above the water bath at the beginning of the 36-h period. At the end of the 36 -h period the slab was completely immersed in the $3^{\circ} \mathrm{C}$ water. For the apparatus designed to cause moisture to migrate to the top of the cheese slab, positions 1 through 6 of the cheese slabs were immersed in the $27^{\circ} \mathrm{C}$ water bath, and position 7 was exposed to the $3^{\circ} \mathrm{C}$ air above the surface of the water bath at the start of the 36 -h period. The slabs were gradually raised during the $36 \mathrm{~h}$ such that at the end of the $36 \mathrm{~h}$ all seven positions were exposed to the $3^{\circ} \mathrm{C}$ air. The slabs were removed after $36 \mathrm{~h}$ and
Metal bar to attach bag to suspension wire

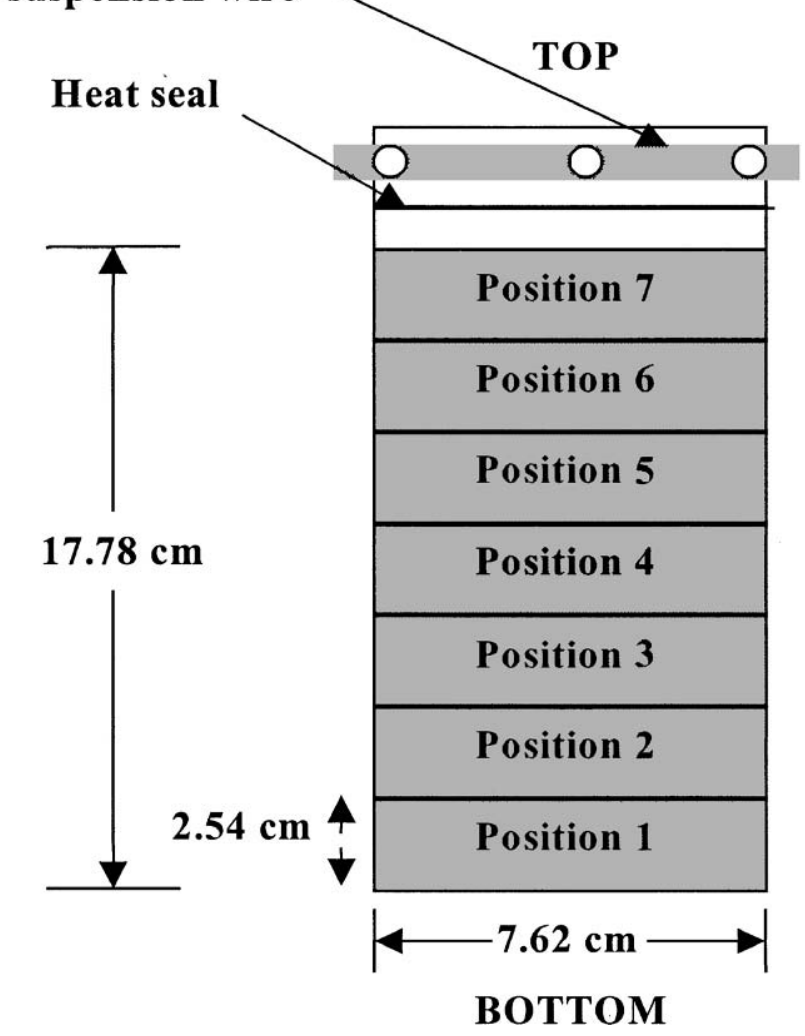

Figure 2. Cheese slab (2.54-cm thick) vacuum packaged and heat sealed in a plastic bag marked with seven positions. A metal bar was attached to the top of the bag to suspend the slab in the temperature gradient apparatus.

cut with a knife into $2.54-\mathrm{cm}$ pieces by position and placed in a cooler at $4^{\circ} \mathrm{C}$. The $4^{\circ} \mathrm{C}$ cheese from each position was ground in a blender (model 31BL92; Waring, New Hartford, CT) and placed into two 50-ml plastic snap-lid vials (leaving no head space) and held at $4^{\circ} \mathrm{C}$ for $\mathrm{pH}$ and moisture analyses. The $\mathrm{pH}$ of cheese from each position within each slab was measured at $23^{\circ} \mathrm{C}$ as a single measurement, and the moisture content of the cheese within each position was measured in triplicate.

\section{Chemical Analyses}

To prepare the seventh slab of cheese for moisture, fat, protein, salt, and $\mathrm{pH}$ determination, the cold cheese was ground in a blender (model 31BL92; Waring, New Hartford, CT) to a particle size of 2 to $3 \mathrm{~mm}$. The ground cheese particles were packed into $50-\mathrm{ml}$ plastic snap-lid vials (leaving no head space) and immediately placed back in a $4^{\circ} \mathrm{C}$ refrigerator. Fat content was determined by the Babcock method [(Mar- 
shall, 1992); method number 15.8.A] using $9 \mathrm{~g}$ of cheese and $12 \mathrm{ml}$ of distilled water; total nitrogen was determined by Kjeldahl using a 1-g sample size [(Association of Official Analytical Chemists, 2000); method number 33.2.11; 991.20]; salt was determined by the Volhard test [(Marshall, 1992); method number 15.5B]; and moisture was determined gravimetrically, by drying $2 \mathrm{~g}$ of cheese at $100^{\circ} \mathrm{C}$ in a forced-air oven (model OV-490A-2; Blue M, Blue Island, IL) for $24 \mathrm{~h}$ [(Association of Official Analytical Chemists, 2000); method number 33.2.44; 990.20]. The $\mathrm{pH}$ of the ground cheese was determined at $23^{\circ} \mathrm{C}$ using the procedure described above. The analyses were done in duplicate for $\mathrm{pH}$ and salt, in triplicate for fat and total nitrogen and in quadruplicate for moisture.

\section{Experimental Design and Statistical Analysis}

Preliminary test of the apparati. Three vacuumpackaged cheese slabs were placed on each of the two temperature gradient producing apparati. In addition, one temperature control slab (isothermal) was used for each apparatus. One control slab was totally immersed in $27^{\circ} \mathrm{C}$ water (in the $27^{\circ} \mathrm{C}$ room) and another control slab was totally immersed in $3^{\circ} \mathrm{C}$ water (in the $3^{\circ} \mathrm{C}$ room) for $36 \mathrm{~h}$. The moisture content of each position within slab for the three slabs in each temperature gradient apparatus and the two isothermal control slabs were compared.

Temperature gradient driven moisture migration. One vat of reduced-fat Cheddar cheese was made in each of $3 \mathrm{wk}$. For each week, three cheese slabs were put on each temperature gradient apparatus. Moisture content of each position for the three slabs within the same temperature gradient apparatus of each week was measured. In the ANOVA model, position was a categorical predictor variable, while cheese making week (i.e., batch of milk) was blocked as a random variable. The interaction term between position and cheese making week was used as the error term for the model. The PROC GLM procedure of SAS was used for all data analyses (SAS version 8.02, 1999-2001, SAS Institute Inc., Cary, NC).

\section{RESULTS AND DISCUSSION}

\section{Preliminary Test of the Apparati}

The moisture content of each position within each slab for both temperature gradient apparati and of the two isothermal slabs are shown in Figure 3. There was no significant moisture migration in the two slabs held under isothermal conditions at 3 and $27^{\circ} \mathrm{C}$. Thus, with very rapid cooling or with no cooling, no moisture gradient develops within a slab. The average moisture

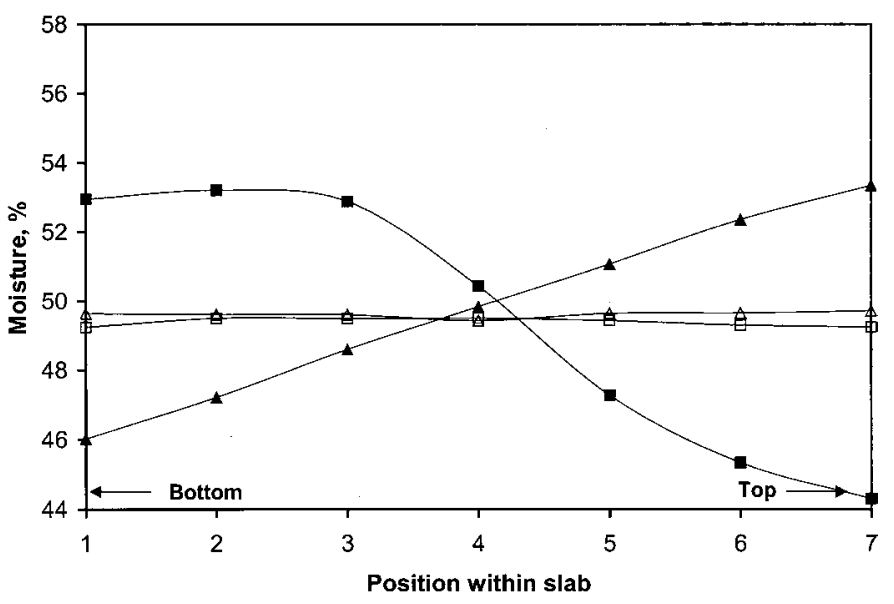

Figure 3. Preliminary test of apparati: cheese moisture as a function of position within slab, position $1=$ bottom $2.54 \mathrm{~cm}$ of cheese slab and position $7=$ top $2.54 \mathrm{~cm}$ of cheese slab. $(\boldsymbol{\Delta})$ Temperature gradient to move moisture upward $\left(27^{\circ} \mathrm{C}\right.$ bath $) ;(\triangle)$ isothermal $27^{\circ} \mathrm{C}$ bath; (ם) temperature gradient to move moisture downward $\left(3^{\circ} \mathrm{C}\right.$ bath); and ( $\square$ ) isothermal $3^{\circ} \mathrm{C}$ bath.

contents of the two isothermal slabs were very similar and were 49.38 and $49.61 \%$ for the 3 and $27^{\circ} \mathrm{C}$ isothermal slabs, respectively. These values were very similar to the average moisture contents of the slabs in the temperature gradient apparati, which were 50.85 and $50.83 \%$ for the temperature gradient to move moisture downward and temperature gradient to move moisture upwards, respectively.

The temperature gradient designed to move moisture upward caused moisture movement upward within each slab from position 1 to 7 (Figure 3). The moisture gradient was linear and changed from 46.02 to $53.34 \%$, with a range of $7.32 \%$. This moisture range is similar to the moisture ranges reported by Barbano (2001) for 290-kg blocks of reduced-fat Cheddar cheese. The temperature gradient designed to move moisture downward within slab caused moisture movement downward from position 7 to 1 . The moisture migration trend was not as linear (Figure 3) as the one obtained with temperature gradient designed to move moisture upward. The moisture change was from 44.3 (top, position 7) to $53.2 \%$ (bottom, position 1) for a range of $8.9 \%$. The preliminary trial demonstrated that the apparati design to produce temperature driven moisture gradients were capable of causing temperature driven moisture movement within Cheddar cheese both in the direction of gravity and against gravity. The ranges of moisture produced within slabs of cheese were similar to those reported for commercial $290 \mathrm{~kg}$ blocks (Barbano, 2001). 
Table 1. Mean $(\mathrm{n}=3)$ reduced-fat Cheddar cheese composition for 3 wk of cheesemaking.

\begin{tabular}{|c|c|c|}
\hline Component & Mean & $\mathrm{SD}$ \\
\hline Fat, $\%$ & 14.06 & 0.34 \\
\hline $\mathrm{CP}, 1 \%$ & 29.39 & 0.96 \\
\hline Moisture, \% & 50.23 & 1.20 \\
\hline MNFS, ${ }^{2} \%$ & 58.44 & 1.18 \\
\hline Salt, $\%$ & 2.21 & 0.08 \\
\hline Salt/Moisture, ${ }^{3} \%$ & 4.40 & 0.10 \\
\hline $\mathrm{pH}$ & 5.06 & 0.06 \\
\hline
\end{tabular}

${ }^{1} \mathrm{CP}=\mathrm{TN} \times 6.38$.

${ }^{2} \mathrm{MNFS}=$ Moisture in nonfat substance.

${ }^{3}$ Salt/Moisture $=$ Salt concentration in moisture.

\section{Temperature-Gradient Driven Moisture Migration}

The average composition of the reduced-fat Cheddar cheese from 3 wk of cheese making is shown in Table 1. The composition was similar to $50 \%$ fat-reduced Cheddar cheese produced in other research studies (Metzger and Mistry, 1995; Chen et al., 1998; Fenelon et al., 1999; Johnson et al., 2001). The average moisture content for the cheese slabs made in $3 \mathrm{wk}$ in the two temperature gradient apparati are shown in Figure 4 . The trends (Figure 4) are the same as those observed in the preliminary data (Figure 3 ). The moisture content for the different positions of the temperature gradient designed to move moisture downward changed from 45.21 (position 7, top) to $54.88 \%$ (position 1 , bottom), with a range of $9.67 \%$. The average moisture content of the temperature gradient de-

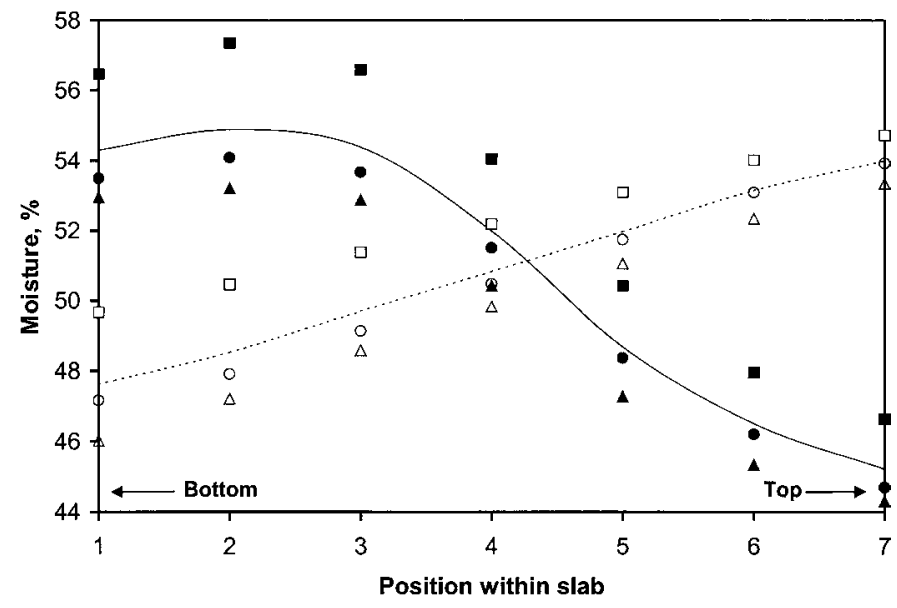

Figure 4. Cheese moisture as a function of position within slab $(\mathrm{n}=3)$, position $1=$ bottom $2.54 \mathrm{~cm}$ of cheese slab and position $7=$ top $2.54 \mathrm{~cm}$ of cheese slab. Moisture gradient apparatus to move

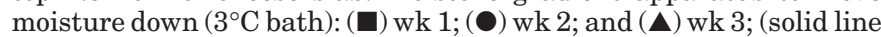
is the average of $3 \mathrm{wk}$ for the apparatus to move moisture downward). Moisture gradient apparatus to move moisture up $\left(27^{\circ} \mathrm{C}\right.$ bath): ( $\square$ ) wk $1 ;(\bigcirc)$ wk 2 ; and $(\triangle)$ wk 3 ; (dashed line is the average of $3 \mathrm{wk}$ for the apparatus to move moisture upward). signed to move moisture upward changed from 47.62 (position 1, bottom) to $53.99 \%$ (position 7 , top), with a range of $6.37 \%$. The moisture range was larger for the temperature gradient apparatus to move moisture downward. This was due to the combined effect of gravity and the temperature gradient, which allowed more moisture migration. This phenomenon has been reported by Barbano (2001), in 290-kg reduced-fat Cheddar blocks.

A significant effect of temperature gradient on the moisture content and $\mathrm{pH}$ among positions within cheese slabs in both temperature gradient apparati was observed (Table 2). As observed in the preliminary work (Figure 3), the moisture migration as a function of position within slab in the temperature gradient designed to move moisture downward was not as linear as the one obtained with the temperature gradient designed to move moisture upward. The three bottom positions (i.e., 1, 2, and 3) in the slabs for the temperature gradient apparatus designed to move moisture downward had similar moisture contents. This apparatus used the $3^{\circ} \mathrm{C}$ water bath in the $27^{\circ} \mathrm{C}$ walk-in cooler. The fans for movement of air in this walk-in cooler were much smaller than those in the $3^{\circ} \mathrm{C}$ walkin cooler for the other apparatus. Thus, the air space about $5 \mathrm{~cm}$ above the water surface in the $3^{\circ} \mathrm{C}$ water bath was not at $27^{\circ} \mathrm{C}$, but was at a temperature lower than $27^{\circ} \mathrm{C}$. Thus, for the first $12 \mathrm{~h}$ of the $36 \mathrm{~h}$, the cheese in positions 2 and 3 were at a temperature lower than $27^{\circ} \mathrm{C}$. The gradient in positions 4 through 7 was more linear. In the second apparatus, which was designed to move moisture upward, the air flow in the $3^{\circ} \mathrm{C}$ walk-in cooler was much greater than in the $27^{\circ} \mathrm{C}$ walk-in cooler. As a result, there was a much sharper change in temperature at the surface of the $27^{\circ} \mathrm{C}$ water bath, with position 7 quickly cooling to $3^{\circ} \mathrm{C}$, while positions 1 through 6 were maintained at $27^{\circ} \mathrm{C}$ during the start of the $36-\mathrm{h}$ run. This produced a much more linear gradient of temperature and moisture within the cheese slabs as they were gradually raised out of the $27^{\circ} \mathrm{C}$ water into the $3^{\circ} \mathrm{C}$ air in the apparatus designed to move moisture upward. This experiment demonstrated that a temperature gradient from $27^{\circ} \mathrm{C}$ to $3^{\circ} \mathrm{C}$ in Cheddar cheese immediately after pressing can cause moisture to move from warm areas to cold areas of cheese both with and against the force of gravity, as reported for commercial 290-kg blocks of reduced-fat Cheddar cheese (Barbano, 2001).

Reinbold et al. (1992a) indicated that further work was needed to determine whether moisture transfers in response to $\mathrm{pH}$ gradient in the cheese created by the temperature gradient, or if moisture migration is due to a direct effect of temperature on the cheese components. The $\mathrm{pH}$ of cheese by position is shown in 
Table 2. ANOVA (degrees of freedom, means squares, probabilities in parenthesis and $\mathrm{R}^{2}$ ) to determine whether significant differences in moisture or $\mathrm{pH}$ among positions within slab were created by temperature gradients produced in the cheese during cooling.

\begin{tabular}{|c|c|c|c|c|c|c|c|}
\hline \multirow[b]{2}{*}{ Factor } & \multirow[b]{2}{*}{$\mathrm{n}$} & \multirow[b]{2}{*}{ df } & \multicolumn{2}{|c|}{$\begin{array}{l}\text { Temperature gradient } \\
\text { to move moisture down }\end{array}$} & \multicolumn{2}{|c|}{$\begin{array}{l}\text { Temperature gradient } \\
\text { to move moisture up }\end{array}$} & \multirow[b]{2}{*}{ Type } \\
\hline & & & Moisture & $\mathrm{pH}$ & Moisture & $\mathrm{pH}$ & \\
\hline Position (P) & 7 & 6 & $\begin{array}{l}48.716 \\
(P<0.01)\end{array}$ & $\begin{array}{l}0.015 \\
(P<0.01)\end{array}$ & $\begin{array}{l}17.659 \\
(P<0.01)\end{array}$ & $\begin{array}{c}0.0024 \\
(0.0195)\end{array}$ & Category \\
\hline Week (W) & 3 & 2 & $\begin{array}{l}20.753 \\
(P<0.01)\end{array}$ & $\begin{array}{l}0.012 \\
(P<0.01)\end{array}$ & $\begin{array}{l}11.395 \\
(P<0.01)\end{array}$ & $\begin{array}{l}0.0146 \\
(P<0.01)\end{array}$ & Blocked \\
\hline $\begin{array}{l}\text { Error } \\
(\mathrm{P} \times \mathrm{W})\end{array}$ & & 12 & 0.136 & 0.0006 & 0.276 & 0.0006 & \\
\hline $\mathrm{R}^{2}$ & & & 0.995 & 0.941 & 0.975 & 0.859 & \\
\hline
\end{tabular}

Figure 5. A significant effect (Table 2) of the temperature gradient on $\mathrm{pH}$ by position within slab was observed for both temperature gradient apparati, but the effect on $\mathrm{pH}$ was much stronger in the apparatus designed to move moisture downward, particularly in positions 1,2 , and 3 . As mentioned above in the discussion of moisture migration, positions 2 and 3 cooled faster than they should have because of poor air circulation in the $5 \mathrm{~cm}$ above the water surface. This premature cooling of positions 1,2 , and 3 in the apparatus stopped the acid production by the starter and produced a higher $\mathrm{pH}$ than in positions 4 through 7 . The effect of the temperature gradient on $\mathrm{pH}$ within slab was much less (Table 2, Figure 5) for cheese in the apparatus designed to move moisture upward, with a total range in $\mathrm{pH}$ of approximately 0.1 units. While cheese $\mathrm{pH}$ may have some influence on the mobility

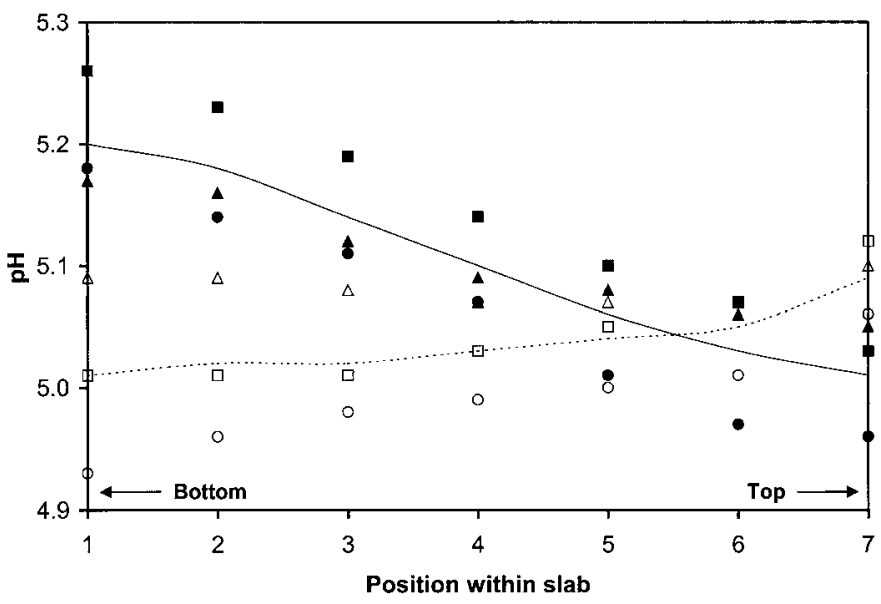

Figure 5. Cheese $\mathrm{pH}$ as a function of position within slab $(\mathrm{n}=3)$, position 1 = bottom $2.54 \mathrm{~cm}$ of cheese slab and position $7=$ top 2.54 $\mathrm{cm}$ of cheese slab. Moisture gradient apparatus to move moisture

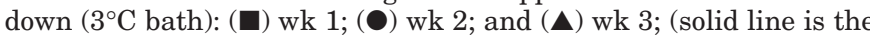
average of $3 \mathrm{wk}$ for the apparatus to move moisture downward). Moisture gradient apparatus to move moisture up $\left(27^{\circ} \mathrm{C}\right.$ bath): ( $\square$ ) wk $1 ;(\bigcirc)$ wk 2 ; and $(\triangle)$ wk 3 ; (dashed line is the average of 3 wk for the apparatus to move moisture upward). of moisture, it appears that the direct effect of the temperature gradient on the ability of the casein to hold or release water may be more important. Caseins are relatively hydrophobic proteins (Swaisgood, 1992). Low temperature environments cause hydrophobic proteins to favor protein-water interactions, while high temperature environments favor protein-protein interactions (Lehninger, 1970). In the warm center position of a cooling $290-\mathrm{kg}$ block of Cheddar cheese hydrophobic protein-protein interactions are favored, while in the cold cheese at the exterior surfaces of the 290-kg block of Cheddar cheese protein-water interactions are favored.

During the first few days after cheese is produced, the mobility of water decreases. This has been demonstrated both in Mozzarella using expressible serum measurements (Guo and Kindstedt, 1995; Guo et al., 1997; Kindstedt and Guo, 1998), and it is expected that similar behavior occurs in Cheddar cheese. The combination of the mobility of a portion of the water within cheese during the first few days after manufacture plus the impact of temperature on the affinity of the casein matrix of the cheese for moisture may explain the large moisture gradients that develop (Barbano, 2001) in 290-kg blocks of reduced-fat Cheddar cheese.

\section{CONCLUSIONS}

It was demonstrated that a temperature gradient could cause moisture to move from areas of warm temperature (i.e., $27^{\circ} \mathrm{C}$ ) to areas of cold temperature (i.e., $3^{\circ} \mathrm{C}$ ) within a block both with and against the force of gravity. The extent of temperature induced moisture migration within cheese produced in this study was comparable to that observed in commercial $290-\mathrm{kg}$ reduced-fat Cheddar blocks (Barbano, 2001).

The apparati designed and evaluated in this work could be used in small scale-pilot plant studies designed to develop cheese-making strategies to prevent 
moisture migration in 290-kg Cheddar cheese blocks. It was easier to control temperatures in the temperature gradient apparatus designed to move moisture upward within a block of cheese, and this apparatus produced more linear moisture gradients with less difference in cheese $\mathrm{pH}$ among positions within the slabs of cheese. It appeared that the direct effect of the temperature gradient on the affinity of the casein matrix of the cheese to absorb or release water was more important than the impact of a $\mathrm{pH}$ gradient produced within the cheese by the temperature gradient.

\section{ACKNOWLEDGMENTS}

The authors thank Tom Burke, Joanna Lynch, Maureen Chapman, Laura Landolf, Pat Wood and Bob Kaltaler for technical support and the Northeast Dairy Foods Research Center and Dairy Management Inc. (Rosemont, IL) for financial support.

\section{REFERENCES}

Association of Official Analytical Chemists, International. 2000. Official Methods of Analysis. 17th ed. AOAC, Gaithersburg, MD.

Barbano, D. M. 2001. Moisture nonuniformity and sampling errors in large Cheddar cheese blocks. J. AOAC Int. 84:613-619.

Chen, M., J. Irudayaraj, and D. J. McMahon. 1998. Examination of full fat and reduced fat cheddar cheese during ripening by Fourier transform infrared spectroscopy. J. Dairy Sci. 81:2791-2797.

Fenelon, M. A., M. P. Ryan, M. C. Rea, T. P. Guinee, R. P. Ross, C. Hill, and D. Harrington. 1999. Elevated temperature ripening of reduced fat Cheddar made with or without Lacticin 3147producing starter culture. J. Dairy Sci. 82:10-22.

Guo, M. R., J. A. Gilmore, and P. S. Kindstedt. 1997. Effect of sodium chloride on the serum phase of Mozzarella cheese. J. Dairy Sci. 80:3092-3098.

Guo, M. R., and P. S. Kindstedt. 1995. Age-related changes in the water phase of Mozzarella cheese. J. Dairy Sci. 78:2099-2107.

Johnson, M. E., C. M. Chen, and J. J. Jaeggi. 2001. Effect of rennet coagulation time on composition, yield, and quality of reducedfat Cheddar cheese. J. Dairy Sci. 84:1027-1033.

Kindstedt, P. S., and M. R. Guo. 1998. A physico-chemical approach to the structure and function of mozzarella cheese. Aust. J. Dairy Technol. 53:70-73.

Lehninger, A. L. 1970. Biochemistry: The Molecular Basis of Cell Structure and Function. Worth Publishers, Inc., New York.

Marshall, R. T. 1992. Chemical and physical methods. Pages 433529 in Standard Methods for the Examination of Dairy Products. 16th ed. American Public Health Association, Washington, DC.

Mesa-Dishington, J. K., D. M. Barbano, and R. D. Aplin. 1987. Cheddar cheese manufacturing cost: Economies of size and effects of different technologies. Agricultural Research Bulletin 87-3. Cornell University, Ithaca, NY. p 1-85.

Metzger, L. E., and V. V. Mistry. 1995. A new approach using homogenization of cream in the manufacture of reduced fat Cheddar cheese. 2. Microstructure, fat globule, and free oil. J. Dairy Sci. 78:1883-1895.

Reinbold, R. S., and C. A. Ernstrom. 1988. Effect of nonuniform cooling on moisture, salt, and $\mathrm{pH}$ distribution in $290 \mathrm{~kg}$ blocks of stirred-curd Cheddar cheese. J. Dairy Sci. 71:1499-1506.

Reinbold, R. S., C. A. Ernstrom, and C. L. Hansen. 1992a. Temperature, $\mathrm{pH}$, and moisture profiles during cooling of $290 \mathrm{~kg}$ stirredcurd Cheddar cheese blocks. J. Dairy Sci. 75:2071-2082.

Reinbold, R. S., C. A. Ernstrom, and C. L. Hansen. 1992b. Effect of container materials on temperature profiles of large blocks of Swiss and Cheddar cheese. J. Dairy Sci. 75:2637-2647.

Swaisgood, H. E. 1992. Chemistry of the caseins. Pages 63-110 in Advanced Dairy Chemistry. Proteins. Vol. 1. P. F. Fox, ed. Elsevier Applied Science, Essex, England. 